\title{
The Difficulties in Implementing Scientific Approach Based on 2013 Curriculum: A Case Study on One English Teacher
}

\author{
Sarah Madina and Absharini Kardena \\ IAIN Bukittinggi, Bukittinggi, Indonesia \\ sarahmadina98@gmail.com
}

\section{ARTICLE HISTORY \\ Received : 24 December 2020 \\ Revised : 19 January 2021 \\ Accepted : 1 April 2021}

\section{KEYWORDS}

Scientific Approach

Curriculum 2013

English Teaching

Implementation

Teaching Adaptation

\begin{abstract}
This case study investigated the difficulties faced by an English teacher in implementing the scientific approach at one selected school in the district of Agam in West Sumatera, Indonesia. This qualitative research used semi-structured interview questions and an observation checklist as the instruments, with an English teacher as the data source. This study showed that the selected secondary English teacher in MTsN 3 Agam encountered eight significant difficulties in dealing with the implementation of stages of the scientific approach based on the 2013 curriculum in classroom activities. The English teacher's difficulties included: (1) to determine the object that will be observed; (2) to determine how the way data recorded; (3) encouraging the students to ask; (4) to make the various media as the information resources; (5) deciding the duration of students to do the experiment activity; (6) to divide the time for evaluation; (7) to organize the student to analyze; (8) encouraging the student to present their work in front of the class. This study serves as a reminder for the preparation suitable strategies needed in adapting not only to the general teaching process, but also to the possible changes in the curriculum.
\end{abstract}

\section{Introduction}

In early 2013, the Ministry of Education and Culture designed a new curriculum called the 2013 curriculum which aims to improve and balance the competency of attitude, knowledge, and skill. Attitudes are acquired through activities; accept, execute, respect, appreciate, and practice (Zaim, 2017). The 2013 curriculum uses the scientific approach as an approach in the learning process. Students in the scientific process are actively involved in learning and being centered. Nugroho, Siti, \& Suherdi (2017) said that the scientific approach was promoted by the 2013 curriculum. This approach also emphasizes the process of searching knowledge and students as the subject of learning through applying scientific principles.

However, based on the preliminary research in MTsN 3 Agam, there are several indications of difficulties faced by an English teacher in implementing the scientific approach based on the 2013 curriculum. There are several studies that explored teachers' difficulty in implementing the 2013 curriculum. Darnius (2016) in Syiah Kuala University acquired data from the questionnaire, observation, and interview of 15 teachers and revealed that they all still found difficulty in applying the scientific approach, hence, the learning process did not run as expected.

Krisdiana, Apriandi, \& Apriansyah (2013) examined the teacher and the student's difficulties in implementing the 2013 curriculum in the mathematic subject on student junior high school. From the observation and interview, it found that the teacher faced the following problem: (1) the teacher did not understand the purpose of the 2013 curriculum and scientific approach, (2) the teacher was not able to carry out the learning process that leads to applicative skills, (3) the learning process did not inspire the students to do the observation and experiment, (4) the teacher was less able to foster the student's creativity in the science learning activity. Besides, They claimed that there was a lack of training of the 2013 curriculum and less ofsupportive facilities and infrastructure in implementing the scientific approach of the 2013 curriculum.

Adriantoni \& Fitrisnis (2018) examined the problems and solutions to the implementation of the 2013 curriculum in junior high school. Based on their observation class, interview, and documentation, they found that the teachers were lack of understanding about the 2013 curriculum concepts, limited time, and there were so many types of assessments in the 2013 curriculum.

Retnawati, Hadi, \& Nugroho (2016) researched teacher's difficulty in implementing assessment in the 2013 curriculum in vocational high school. This study was quite different because it was talking about the assessment. However, it was related to investigating the study under the topic of the 2013 curriculum. From the interview and focus group discussion, they proved that the teachers had not fully understood the assessment system. Besides, the teacher 
could not find afeasible application for describing the student's learning achievement.

Based on the problem above, this research intended to conduct the research about the indication of difficulties in scientific stages. The difficulties might occur in some stages such as observing, questioning, experimenting, associating or communicating stage. Indeed, it is important to research the title: English Teacher's difficulties in implementing scientific approach based on 2013 curriculum at eighth grade of MTsN 3 Agam. This study guide by a question of what are the difficulties faced by the English teacher in five stages in the scientific approach that is observing, questioning, experimenting, associating, and communicating.

The result of this study aims to be a contribution for the next researcher and expert to find out the solution for those teacher's difficulties in applying the scientific approach, especially in the 2013 curriculum. Besides, it can serve as a reminder to the teacher to improve and increase their competency skill in the teaching-learning process of the scientific approach of the 2013 curriculum.

\section{Literature Review}

\subsection{Curriculum}

The curriculum of 2013 is competency and characterbased curriculum. It was born as a response to the various criticisms of School-Based Curriculum 2006. As stated by Rusman (2016) in his book that the development of the 2013 curriculum is the advanced step of Competence-based Curriculum (2004) and School-Based Curriculum (2006) that covering of the competency of attitude, knowledge, and skill in an integrated way. The orientation of this curriculum is to improve and balance soft skills and hard skills which involves the competencies of knowledge, skill, and attitude. Gunawan (2015) said that the objective of the 2013 curriculum is creating productivity, creativity, and innovation, through strengthening affective attitudes, skills, and integrated knowledge for Indonesians. In conclusion, the 2013 curriculum is developed to face the future challenges facing by Indonesia which involves the three competencies (skill, knowledge, and attitude) with balancing soft skill and hard skill.

\subsection{Scientific Approach}

In reaching those orientations, the 2013 curriculum promoted the scientific approach. According to the Ministry of Education and Culture, the 2013 curriculum applies the scientific approach as its ways of teaching and learning activity. The scientific approach is a learning process that used scientific steps in the learning process. The learning model needed by the scientific approach is learning which allows learners to have science thinking skills and developing the sense of inquiry and the ability of creative thinking of learners (Majid \& Chaerul, 2014). According to Hosnan (2016), the purposes of the scientific approach are to improve student'scritical thinking, to help the student to have the ability of problem-solving, to create a positive atmosphere in the classroom so that the student will feel that they need to study in the classroom, to develop students' characters, and to give the chance for the student to state their arguments, especially in writing scientific articles". This approach has five ways of thinking to arrive at the truth (knowledge) namely observing, questioning, experimenting, associating, and communicating.

\subsection{The Steps of Scientific Approach}

Observation is the activity where learners use the sense of sight (reading), smell, hearing (listening), taste, and touch to identify an object with or without any tool. The observing activities might be environment observation, observing any picture, video, chart, and diagram data, analyzing any map, reading any form of information from any kind of source. In summary, the form of learning result of this activity is students could identify the problem. The second stage is questioning. In this activity, students can express their curiosity about something which relates to any object, event, or certain process.

In questioning activity, students make the question in individual or group about something they are wondering about. Students can ask the question to the teacher, informant, other students, and to herself under teacher guidance so that student can being independent and it can be a habit.

The next step is experimenting. The experimenting is the activity where the learner collects the information as the material to analyze and summing up. Experimenting activity could be done by reading some books, collecting secondary data, field observing, experiment, interviews, distribute the questionnaire, and so on. Thus, the student could test the hypothesis in this activity. It is the activity in which students process the data in form of a series of physical activities and thought which are helped by a certain tool.

Next is associating activity. There are many kinds of associating activity, for instance,clarify, sorting, counting, dividing, and arrange the data in informative form, and also determine the source of the data so it could be meaningful. Much activity could be done in associating activity such as make a table, diagram, and chart, graphic, the main map, counting, and modeling. Furthermore, the student analyzes the data to compare and determine the data processed and the theory that was used. Therefore, the conclusion can be drawn; principles and important concepts can be found. Hence, the student can conclude the study result from that hypothesis.

The last is communicating, in this activity, students have to present the result of the products, make a conclusion based on the results of the analysis orally, written, or other media in this step. The activity can be concluded by the students in communicating step is presenting their work. Indeed, the student can formulate and take responsibility forhypothesis verification (Ministry Education and Culture, 2013).

\section{Method}


This research aims to describe how does the English teacher implementsthe scientific approach based on the 2013 curriculum and what are the difficulties faced by the English teacher in implementing the scientific approach based on the 2013 curriculum at eighth grade of MTsN 3 Agam. Therefore, qualitative research has been conducted by the researcher in descriptive study form. Agustinova (2015) mentions that qualitative research is a research procedural which is done naturally according to what happened in the setting without making any treatment and the kind of data collected is descriptive data.

In this study, the data sources of this research are the English Teacher from the grade of MTsN 3 Agam and 30 students from VIII-1 of MTsN 3 Agam. Those informants are based on purposive sampling and the facility of the informants. The data was collected by using classroom observation and interviews. The observation checklist is going to answer the first question of question research that is the implementation of the scientific approach based on the 2013 curriculum of English teachers in MTsN 3 Agam. Moreover, by interviewing English teachers, it can share the information about what are the difficulties in implementing the scientific approach based on the 2013 curriculum in the learning process.

\section{Results}

The result is the finding from twenty indicators covering the five stages of the scientific approach. The data collected from observation class and interview are revealing in the following section:

\subsection{Observing}

Observing is the first stage in implementing the scientific approach. It has seven steps that have to be conducting. Thus, those seven steps were observed and researched by observation class and interview:

Table 1.Observation Sheet of Observing Stage

\begin{tabular}{|c|c|c|c|}
\hline NO & OBSERVATION ASPECTS & YES & $\mathrm{NO}$ \\
\hline 1 & The teacher determines the object that will be observed. & $\checkmark$ & \\
\hline 2 & The teacher makes the observation guideline according to the object that will be observed & & $\checkmark$ \\
\hline 3 & $\begin{array}{l}\text { The teacher determines the data that will be observed clearly, whether it is primary data or } \\
\text { secondary data }\end{array}$ & $\checkmark$ & \\
\hline 4 & The teacher determine where the object that will be observed is. & & $\checkmark$ \\
\hline 5 & $\begin{array}{l}\text { The teacher determines how the observation will be conducted to collect the data clearly so that it } \\
\text { can run as smooth and easy }\end{array}$ & $\checkmark$ & \\
\hline 6 & $\begin{array}{l}\text { The teacher determines how the way data recording, in case of using the notebook, camera, tape } \\
\text { recorder, video recorder, and other stationery }\end{array}$ & $\checkmark$ & \\
\hline
\end{tabular}

Table 1 displays how the teacher implementing the observing stage in the class. However, it does still not demonstrate the difficulty faced by the teacher so an interview is needed. Each point was asked for the teacher to dig further about his difficulty. It is explaining in the following:

$\mathrm{R}$ : "What is your difficulty in guiding the students to determine the object that will be observed?"

T: "My difficulty in this matter is to determine the object or the event in this location of the school. Because of the available number of media and facility that will be observed was less compared with the needs of the students."

$\mathrm{R}$ : "What is your difficulty in helping the students to prepare the observation guideline according to the object that will be observed?"

$\mathrm{T}$ : "The problem is to arrange that observation guideline with the students. Because all of the steps to observe should be included in the observation guideline, on the other hand, the students did not understand the observation activity yet."

$\mathrm{R}$ : "Is it not the teacher's duty to direct the students to prepare the observation guideline for the observation?

T: "Yes, it is something the teacher has to work on. Here, the teacher has to teach the students to prepare the observation guideline, whereas the core material has not been entered. So, it is a challenge for the teacher to prepare matters related to scientific activities whereas many indicators must be pursued in learning. Since the observation guideline already exists in the textbook and the time is limited, so that's what is used."

$\mathrm{R}$ : "What is your difficulty in explaining to the students about the kind of data? Whether it is the primary data or secondary data."

$\mathrm{T}$ : "There is no difficulty or problem in this matter. So far the students can understand the types of data supported by the clear example. And no one obstacle in explaining this indicator to the students."

$\mathrm{R}$ : "What is the teacher's difficulty in directing the students to determine where the object will be observed?"

$\mathrm{T}$ : "Honestly, it was seldom for me to discuss it with the students. However, there is no problem relating to the location of the observation, the activity of observation was done in class; so far there was no obstacle in"

$\mathrm{R}$ : "What is the teacher's difficulty in explaining the students to determine how the observation will be conducted?"

T: "no difficulty in determining how the observation will be conducted because the observation guideline had helped the students to conduct this activity. However, some of the students are not always using the guideline from the textbook. They using their way to identify and collect the data. For me, it does not matter as long as the students can reach the purpose of this activity." 
$\mathrm{R}$ : "What is teacher's difficulty in directing the students to determine how the data will be recorded?"

$\mathrm{T}$ : "To record the data, the problem is limited activity in recording the data. the most activity in recording the data is write down the information to the book. Since the school forbid the students to bring any electronic tools into the class, So I have a hard time to make the variety of activities in record and collect the data."

\section{Interview Excerpts 1}

English teacher has two difficulties dealing with conducting the observation stage of the scientific approach they are determining the object that will be observed and determine how the way data recorded. The first problem is caused by the lack of the number of objects and events that exist in the location of the school. The reality in the field answered that it was caused by the teacher could not utilize the environment as the object or the observation material. The learning process was too fixated on the textbook which students have. Besides, the teacher has roblem in determining how to record the data while the school prohibits the students to bring the electronic devices. Thus, it was difficult for techer to make the various activity dealing with the media and the device which were available in the school.

\subsection{Questioning}

In this stage, the teacher tries to guide the student to ask for the material they do not understand or getting discussed with the teacher and among the students about the topic which is similar toin the observing stage. There are two indicators for teacher in doing questioning stage:

Table 2. Observation Sheet of Questioning Stage

\begin{tabular}{|c|c|c|c|}
\hline $\mathrm{NO}$ & OBSERVATION ASPECTS & YES & $\mathrm{NO}$ \\
\hline 7 & Teachers must be able to inspire the learners to ask by making interesting media. & $\checkmark$ & \\
\hline 8 & $\begin{array}{l}\text { When the teacher asks the question, the teacher leads the learners to ask in a good way. When the } \\
\text { teacher answers the question, the teacher guides the learners to be good listeners. }\end{array}$ & & $\checkmark$ \\
\hline 9 & Teachers' question aims to get the verbal response. & $\checkmark$ & \\
\hline
\end{tabular}

The transcription is also displayed as complementary in the finding section. It explains as the following:

$\mathrm{R}$ : "What is teacher difficulty in inspiring the students to ask by making the interesting media?"

T: "To inspire the students in asking needs more strategy, I thought that it might take time to use the different strategy to encourage students to ask. Meanwhile, the teacher had to spend more time in the experimenting stage."

R: "What is the teacher's difficulty in leading the students to ask in a good way?"

$\mathrm{T}$ : "There is no significant problem in this aspect. Because of some students were seen feel afraid of making mistakes especially speaking in English.”

$\mathrm{R}$ : "What is the teacher's difficulty in getting the verbal response from the students?"

$\mathrm{T}$ : "The problem is just there were a few of them who dare to ask the question. It is not a big problem. To make sure that they understand the topic that is discussed, I will ask back to them. The students who dare to speak or ask the question will get ascore for their bravery. It was enough to make the students give the verbal responses I thought."

Interview Excerpts 2

The teacher had a problem in applying various strategies to encourage students to ask. Questioning should be an activity to actively asking about a certain topic. However, not all of the students can directly ask the question. The students sometimes seek confusion about what topic that has to be asked for. Hence, it can be said that the teacher was unable to encourage the students to ask.

\subsection{Experimenting}

The experimenting stage was conducted after the questioning stage whereas the students were guided to do the attempting or collect the data. In this case, the teacher asked the students to collect the data by using some books.

Table 3.Observation Sheet of Experimenting Stage

\begin{tabular}{llll}
\hline NO & OBSERVATION ASPECTS & YES & NO \\
\hline 10 & The teacher states the purpose of the experiment that will be conducted. & $\checkmark$ & \\
11 & Teacher and learners prepare the material and tool that will be used. & $\checkmark$ \\
12 & The teacher determines the place and time. & $\checkmark$ \\
13 & The teacher stated the problem that will be experimented with. & $\checkmark$ \\
14 & The teacher shares the paper sheet withthe learners. & $\checkmark$ & \\
15 & Learners experiment with teachers' guidance. & & $\checkmark$ \\
16 & The teacher collects the students' work and does the evaluation & \\
\hline
\end{tabular}


To investigate the difficulties of the teacher of this activity, here is the finding of the interview section on experimenting activity with the teacher:

$\mathrm{R}$ : "What is the teacher's difficulty to state the purpose of the experiment that will be conducted?"

T: "In this case, before state the purpose of the activity given to the students, the teacher had to think what is the activity which is suitable with this lesson. It was one of the problems in the experimenting activity. I usually got the students to complete the task on the textbook as the activity to collect the information. It would be better if the students were granted permission to use the mobile phone. It would be fun maybe."

$\mathrm{R}$ : "What is the teacher's difficulty in preparing the material and tools in the experiment stage with the students?"

T: "Material and tools are usually needed at a certain activity such as the attempting activity in procedural text. It must be notified early to the student so the students had brought the material and tool which needed. If the activity was only completing the task on the textbook, there is no need to preparing the material or tools, because it depended on the activity that will be conducted"

$\mathrm{R}$ : "What is the teacher's difficulty in leading the students to determine the time and place of the experiment that will be conducted?"

T: "It was difficult to divide the time in scientific approach while there were a lot of aspects that have to reach. The experiment activity was short, and it caused the students did not effectively work and looking for the complete information."

\section{R: "And how about the place?"}

T: "It was seldom to us to study out of the class because the number of the students was not suitable with the environment which was available in this school"

R: "What is the teacher's difficulty in stating the problem of the experiment?"

$\mathrm{T}$ : "It was fine because it was still conducted by using the textbook. So the teacher just explained the problem which was referring to the textbook."

$\mathrm{R}$ : "What is the teacher's difficulty when shares the paper sheet withthe students?"
$\mathrm{T}$ : "The paper sheet is usually needed at the scientific activity which has the hypothesis. Because our activity was doing the exercises, we did not need it. However, if we use the paper sheet, it is no problem with that. Indeed, it would facilitate the student's activity."

$\mathrm{R}$ : "What is the teacher's difficulty in guiding the students to conduct the experimenting stage?"

T: "There was no significant difficulty about that. As long as we controlled them by walking around the class, they will do their work. But sometimes, they tend to talk to their friend and play around. We just have to give them the warning"

R: "What is the teacher's difficulty in collecting the student's work and do the evaluation?"

T: "The students always submitted their work as should be. The evaluation sometimes conducted in class before associating stage but sometimes it conducted out of the class because of limited time"

Interview Excerpts 3

English teachers in eighth grade can not utilize the media and the environment as learning resources. As a result, the learning activities are not varied, monotonous, and fixated on the textbook that students have. The teacher did not facilitate the students yet with various learning resources. In this case, the teacher was still the learning resources which helped with the textbook.

The teacher also had a hard time to allocate the time for experimenting activity and for evaluation. The experimenting activity was not effectively done by the teacher caused by limited resources and limited time. Besides, evaluation section was missed by the teacher while the evaluation is a tool to know whether the purpose of the activity was reach or not. Therefore, it showed that the experimenting stage was not implemented as well as it should be.

\subsection{Associating}

The data from the experimenting activity were processed in associating stage. It has two activities. They were observed and asked for the teacher as follow:

Table 4. Observation Sheet of Associating Stage

\begin{tabular}{|c|c|c|c|}
\hline NO & OBSERVATION ASPECTS & YES & NO \\
\hline 17 & $\begin{array}{l}\text { The teacher facilitates students to analyze the data in form of a category and determine the } \\
\text { relationship between the data or category. }\end{array}$ & & $\checkmark$ \\
\hline 18 & The teacher facilitates students to conclude the result of data analysis. & $\checkmark$ & \\
\hline
\end{tabular}

$\mathrm{R}$ : What is the teacher's difficulty in guiding the students to analyze the data in form of a category?

T: "The number of the students was quite a lot so the students feel a bit had a hard time discussing the material in the lesson."
$\mathrm{R}$ : "What is the teacher's difficulty in guiding the students to conclude the result of the data analysis?"

T: "To conclude the result of the information which was processing, it was usually made in a table form. The students were asked tomake the table of material 
conclusions in front of the class. The difficulty is to get the student to dare to get along to make the table in front of the class."

\section{Interview Excerpts 4}

The English teacher in eighth grade in MTsN 3 Agam cannot guide the students to analyze the data. Data analyzing us the activity aimed for the student can process the data which gotten from the collecting data activity. In the implementation context of English teaching at eighth grade in MTsN 3 Agam, most activities in associating stage were done individually. Instead, it would be better if the students were guided to discuss in the group. This way is aimed to get students to communicate with their friends, respect other opinions, and be able to process the data into broader information.

\subsection{Communicating}

This activity is the closing stage of the scientific approach learning process. Here, the students lead by the teacher to perform their work and conclude the lesson.

Table 5. Observation Sheet of Communicating Stage

\begin{tabular}{lll}
\hline NO & OBSERVATION ASPECTS & YES \\
\hline 19 & $\begin{array}{l}\text { The teacher facilitates students to be able to communicate their work which is arranged by } \\
\text { individual or group. }\end{array}$ & $\checkmark$ \\
20 & The teacher clarifies so that learners know whether their work is correct or not. & $\checkmark$ \\
\hline
\end{tabular}

This interview transcript tries to descript the teacher's difficulties in implementing the communication stage.

\section{$\mathrm{R}$ : "What is the teacher's difficulty in guiding the student to communicate their work?" \\ T: "In allowing students to come in front of the class, Sometimes I had a hard time motivating them to speak up or arguing about the topic which being discussed because some of the students were shy and doubtful to come in front of the class." \\ $\mathrm{R}$ : "What is the teacher's difficulty in clarifying to students whether their work is correct or not?" \\ T: "There was not a big deal. This clarification section had the teacher give the appropriate feedback. If the students make the mistake, the teacher had to explain the right one without discouraging the students and so does to the student who makes the correct answer, the teacher had to give the good feedback or compliment for them."}

\section{Interview Excerpts 5}

The finding showed that teacher's found the problem to encourage the students to present their work in front of the class. She cannot organize the students to present their work in front of the class. This difficulty was found when the English teacher implemented a scientific approach without making the group discussion in the learning process so that the students were not used to express their opinion in front of other people.

\section{Discussion}

There are some challenges faced by the teacher since the governments implemented the new curriculum called the 2013 curriculum. Based on the observation class and interview, it found that the teacher encounter the following difficults:

The first is the teacher was not able to determine the object that will be observed. It might because the teacher could not utilize the environment as the object or the observation material. The learning process was too fixated on the textbook which students have. This fact is contrary to the mandate of the implementation of the scientific approach in Permendikbud No.81a Tahun 2013 that is in conducting the observation activities, the teacher gives the big opportunity and varies to the students to conduct the observation. The various activities in this context mean that the learning process should not fixate on the textbook. It was suggested to the teacher to improve herself in making the media as the need of teachining learning process and could take the advantagas of the environment of the school as the media.

The second difficulty is determining the variety of tools in recording the data. The recording tools for observation stage could be like recorder, camera, or mobile phone. So this case must be depend on the policy of the school and available facilitates at the school. It should be better if the school had pay attention to the facility of the school so that the learning process will run effectively and efficiently. As Ahmadi \& Supriyono (2008) said that facility is one of the factor that determine the achievement of learning and scientific approach requires the complete facility in order to help the learning process to be interesting so that it can guide the learners to have scientific thinking. Regardless of changes in curriculum, secondary school teachers in general frequently have difficulties in adapting with the advancements of information and communication technology for their classroom learning process (Junaidi et al., 2020 Martaliana, Syahrul, \& Safitri, 2021).

The third teacher's difficulty is encouraging the students to ask. The teacher have to be patience and persistence to guide the students to ask. Besides, the teacher must find a proper and practical way to invite the students to speak. Aulia, Poedjiastoeti, \& Agustini (2020) writes three steps to help the student to ask: (1) give the students a time to make the question by their own; (2) teacher can be the active listener to listen the question from the students sympathetically; (3) teacher provides the list question that 
should be looking for the answer through the learning process.

The next problem is to make the various media as the information resources. Based on the observation class and the interview, most of the collecting data activities was done by reading the books. Instead, collecting data can be done by watching the video, from internet, observation, interview, and etc. so, it can be said that the experiment process was not quite optimal as explained by Sanim (2015) that experimenting activity should be a stage to students to dig up and collect the information from various resources through various ways. However, despite the unreadiness of technology and innovation factors in part of the educators, Rosida, Muin, \& Sakka (2021) showed that the students are ready for these changes, thus teachers should also similarly be motivated to make use of modern media.

The next is deciding the duration for students to do experiment activity and devide the the time for evaluation. Those two difficulties talks about time allocation devided by teacher. Based on the observation class, the students need more time to do the experiment. On the other hand, there are much indicators of the scientific approach which must to conduct in a learning process. The teacher has to make the rules to control the class; the teacher should be able to divide the time for each steps of scientific approach start from observation and communication stage.

The next difficulty is organizing the students to analyze the data in associating activity. Data analyzing is aimed for the student to process the data which gotten from the collecting data activity. Based on the finding section, the most activities in associating stage were done individually. Instead, it would be better if the students guided to discuss in group. This way is aimed to get students communicate with their friends, respect to other opinions, and be able to process the data into the broader information. As confirmed that the associating stage is purposing to make the students able to criticize, assess, compare, interpretation the data, expressing the opinion according to the result of the information collected (Sanim, 2015; Syafiq, Rahmawati, Anwari, \& Oktaviana, 2021).

The last is encouraging the students to show their curiosities in front of the class. This difficulty was basically found when the English teacher she implemented scientific approach without making the group discussion in learning process so that the students were not used to express their opinion in front of other people. Communicating activity has the purpose of enhancing the learning experience of the students by conveying the results of their finding, the conclusion from the analysis data which obtained either orally, in writing, or through other ways or media (Fathurrahman, 2015). This is aimed so that the students have the opportunity to develop their competency in terms of developing the honest, thorough, tolerant, critical thinking, express the opinion, and have the ability to speak properly and correctly (Batubara et al., 2020).
Hence, it can be said that the change of curriculum in the process raised various challenges. The teacher had difficulties because she or he is one of the instruments which run the curriculum. It would better for the teachers to attend the initial training, $M G M P$, seminar, and others training related to the implementation of the 2013 curriculum and scientific approach. Besides, it suggested to the teacher to improve herself in developing the medium and the activities supporting to implementation of the scientific approach based on the 2013 curriculum.

\section{Conclusion}

This study indicates some problems in applying the scientific approach in the learning process of the 2013 curriculum. In all five stages of the scientific approach, the English teacher encountered eight difficulties in total. The teacher had two difficulties in the observing stage, which are how to determine what object that will be observed and how the data should be recorded; one difficulty in the questioning stage, which is how to smooth the oral communication about the material; three difficulties in the experimenting stage, which are how to create different activities with the available media, how to decide the duration of experiments, and how to divide the time for evaluation; one difficulty in the associating stage, which is how to analyze and process the data; and one difficulty in the communicating stage, which is how to encourage the students to present their work in front of the class.

Hence, the teacher needs the strategy to be developed in applying the scientific approach in the learning process. Since this approach has five stages that need to be conducting, so it has to be followed by some strategy and policy supporting by the teacher and school. It also suggested to the teacher to acquire some references and training about implementing the 2013 curriculum and scientific approach.

\section{References}

Agustinova, D. E. (2015). Memahami metode penelitian kualitatif: teori dan praktik. Yogyakarta: Calpulis

Ahmadi, A., \& Widodo, S. (2008). Prestasi belajar. Jakarta: Rineka Cipta

Ahmadi, R. (2014). Metodologi penelitian kualitatif. Yogyakata: Ar-Ruzz Media

Ali, M. 2009. Pengembangan kurikulum di sekolah. Bandung: Sinar Baru Algesindo

Aprison, W., \& Junaidi. (2017). Pendekatan saintifik: melihat arah pembangunan karakter dan peradaban bangsa Indonesia.

Aulia, E. V., Poedjiastoeti, S., \& Agustini, R. (2018). The effectiveness of guided inquiry-based learning material on students' science literacy skills. In Journal of Physics: Conference Series (Vol. 947, No. 1, p. 012049). IOP Publishing. 
Batubara, F., Derin, T., Putri, N. S., \& Yudar, R. S. (2020). Five Factors Influencing the Students' Motivation to Learn English as a Foreign Language: A Closer Look into Montessori Classroom Environment. REiLA : Journal of Research and Innovation in Language, 2(2), 76-84. https://doi.org/10.31849/reila.v2i2.3165

Darnius, S. (2016). Identification teachers' difficulties in implementing 2013 curriculum with scientific approach in high class in sub-district of Banda Aceh. Jurnal Pesona Dasar, 2 (4): 1

Fathurrohman, M. (2015). Paradigma pembelajaran kurikulum 2013: strategi alternatif pembelajaran di era global. Yogyakarta: Kalimedia

Gunawan, I. (2015). Metode penelitian kualitatif: teori dan praktik. Jakarta: Bumi Aksara.

Gunawan, I. (2017). Indonesian 2013 curriculum: instructional management, obstacles faced by teachers in implementing and the way forward advances in social science. Education and Humanities Research, 128, 56

Herdinsyah, H. (2013). Wawancara, observasi, dan focus groups: sebagai instrument penggalian data kualitatif. Depok: Grafindo Persada.

Hosnan, M. (2014). Pendekatan saintifik dan kontekstual dalam pembelajaran abad 21. Bogor: Ghalia Indonesia

Junaidi, J., Hamuddin, B., Simangunsong, W., Rahman, F., \& Derin, T. (2020). ICT usage in teaching English in Pekanbaru: Exploring junior high school teachers' problems. International Journal of Advanced Science and Technology, 29(3), 5052-5063

Kardena, A. (2015). Change of curriculum and its implementation on teachers' performance in EFL class. Proceeding of the Third International Seminar on English Language and Teaching, 46.

Kardena, A. (2019). Teachers' management and implementing for the success of EFL learning, Beyond Word, 7, 71

Kurinasih, I., \& Berlin S. (2014). Implementation of 2013 curriculum: concepts and implementation. Jakarta: Kata Pena.

Majid, A., \& Chaierul, R. (2014). Pendekatan ilmiah dalam implementasi kurikulum 2013. Bandung: Remaja Rosdakarya

Martaliana, L., Syahrul, S., \& Safitri, L. (2021). The Seven Time Managing Strategies of English Teachers to Adapt with the Change in Curriculum. Elsya : Journal of English Language Studies, 3(1), 45-49. https://doi.org/10.31849/elsya.v3i1.5639
Nugraha, I, S., \& Didi , S. (2017). Scientific approach: an english learning teaching (ELT) approach in the 2013 curriculum. Journal of English and Education, 5 (2), 2.

Nunan, D. (2004). The learner-centered curriculum. Cambridge: Cambridge University Press

Ornstein, A. C., \& Hunkins, F., P. (2018). Curriculum: foundations, principles, and isues. England: Pearson Education Limited.

Reflinda. (2017). Purpose, function and principles of language learning evaluation. Jurnal Vision, 11,11

Rosida, A., Muin, S. A., \& Sakka, W. (2021). An Internal Analysis of E-Learning Implementation Readiness: Present Evaluation and Future Planning. Utamax : Journal of Ultimate Research and Trends in Education, 3(1), $1-8$. https://doi.org/10.31849/utamax.v3i1.5715

Rusman. (2016). Pembelajaran tematik terpadu: teori, praktik dan penilaian. Jakarta: Raja Grafindo Persada.

Sabda, S. (2011). Pengembangan kurikulum (tinjauan teoritis). Yogyakarta: Aswaja Pressindo.

Sanim, R., A. (2015). Pembelajaran saintifik untuk implementasi kurikulum 2013. Jakarta: Bumi Aksara.

Syafiq, A. N., Rahmawati, A., Anwari, A., \& Oktaviana, T. (2021). Increasing Speaking Skill through YouTube Video as English Learning Material during Online Learning in Pandemic Covid-19. Elsya : Journal of English Language Studies, 3(1), 50-55. https://doi.org/10.31849/elsya.v3i1.6206

Yusuf, M. (2014). Metode penelitian: kuantitatif, kualitataif \& penelitian gabungan. Jakarta: Prenadamedia Grup.

Zaim, M. (2017). Implementing scientific approach to teach English at senior high school in Indonesia. Asian Social Science, 13(2), 33-40.

Zohrabi, M. (2008).Researching in curriculum component. PAN- pacific assosiation of applied linguistics, 12 (2): 58 . 